Volume 3 Issue 2 (2019) Pages 433-439

Jurnal Obsesi : Jurnal Pendidikan Anak Usia Dini

DOI: 10.31004/obsesi.v3i2.227

\title{
Pengaruh Pola Asuh dan Kekerasan Verbal terhadap Kepercayaan Diri
}

\author{
Asla De Vega ${ }^{1 凶,}$ Hapidin $^{2,}$ Karnadi $^{3}$ \\ Pendidikan Anak Usia Dini, Universitas Negeri Jakarta
}

\begin{abstract}
Abstrak
Kepercayaan diri merupakan kemampuan individu dapat memahami dan yakin akan kapasitas dirinya, yakin mencapai tujuan yang diharapkan, tidak cemas dalam bertindak, hangat dan sopan dalam berinteraksi dan percaya akan kemampuan yang dimilikinya. Penelitian ini bertujuan untuk mengetahui pengaruh pola asuh dan kekerasan verbal terhadap kepercayaan diri pada anak sekolah dasar kota Jakarta Utara. Variabel yang digunakan dalam penelitian ini adalah pola asuh (X1), kekerasan verbal (X2), dan kepercayaan diri (Y). Jenis penelitian ini menggunakan jenis penelitian kuantitatif dengan studi kausal. Jumlah sampel dalam penelitian ini 106 orang dengan menggunakan teknik Cluster random sampling. Alat pengumpulan data berupa kuesioner. Hasil penelitian menunjukkan bahwa pola asuh berpengaruh langsung positif terhadap kepercayaan diri, kekerasan verbal berpengaruh langsung negatif kepercayaan diri, dan pola asuh berpengaruh langsung negatif terhap kekerasan verbal.
\end{abstract}

Kata Kunci: pola asuh; kekerasan verbal; kepercayaan diri

\begin{abstract}
Self-confidence is the ability of an individual to be able to understand and be sure of his capacity, sure to achieve the expected goals, not anxious in acting, warm and polite in interacting and believing in the abilities he has. This study aims to determine the effect of parenting and verbal violence on self-confidence in elementary school children in North Jakarta. The variables used in this study were parenting (X1), verbal violence (X2), and selfconfidence (Y). This type of research uses a type of quantitative research with causal studies. The number of samples in this study were 106 people using the Cluster random sampling technique. Data collection tool in the form of a questionnaire. Based on the calculations obtained that tcount greater than ttable shows that parenting has a positive direct effect on self-confidence, verbal violence has a positive direct positive effect on self-confidence, and pattern-pattern has a positive direct effect on verbal violence.
\end{abstract}

Keywords: parenting; verbal violence; self-confidence

Copyright (c) 2019 Asla De Vega, Hapidin, Karnadi

$\square$ Corresponding author :

Address : Jakarta, Indonesia

Email : asladevega123@gmail.com

ISSN 2356-1327 (Media Cetak) ISSN 2549-8959 (Media Online) 


\section{PENDAHULUAN}

Kepercayaan diri merupakan hal yang sangat penting diajarkan pada setiap individu. Dengan kepercayaan diri, anak mampu mengatasi tantangan yang baru, meyakini diri sendiri dalam keadaan sulit, dan mampu mengembangkan sikap positif tanpa mengawatirkan berbagai situasi dan kondisi. Setiap orang memiliki tingkat kepercayaan diri yang berbeda satu sama lainnya. Seseorang yang memiliki kepercayaan diri yang tinggi, memiliki perasaan positif terhadap dirinya. Orang dengan kepercayaan diri tinggi bukanlah orang yang hanya merasa mampu (Sebetulnya tidak mampu) melainkan adalah orang yang mengetahui bahwa dirinya mampu berdasarkan pengalaman dan perhitungannya. Begitupun sebaliknya, seseorang yang memiliki kepercayaan diri yang rendah, akan memiliki perasaan yang negatif terhadap dirinya, memiliki keyakinan lemah terhadap kemampuan dirinya, anak suka menutup diri, tidak memiliki keberanian dan selalu saja dihantui dengan rasa takut. Oleh karena itu, Kepercayaan diri dipandang sebagai salah satu aspek penting dalam pembentukan kepribadian anak. Sebuah penelitian menyatakan bahwa kepercayaan akan keberhasilan dan kegagalan individu dikendalikan oleh perilaku individu sendiri yaitu perasaan yang berasal dari dalam diri anak atau keyakinan bahwa kita dapat menyelesaikan berbagai tugas atau tujuan sepanjang hidup (Vanaja \& Geetha, 2017). Pentingnya memiliki rasa kepercayaan diri, setiap tempat dan suasana perlu dibangun secara optimal dan positif. Bagi orang tua dan guru diharapkan dapat membantu perkembangan rasa percaya diri pada anak dan sama sama saling menyadari bahwa dengan dimilikinya rasa percaya diri yang positif pada anak akan membawa keuntungan diberbagai pihak. Masa depan anak sangat tergantung dari pengalaman yang didapat anak termasuk faktor pendidikan dan pola asuh orang tua. Hasil penelitian yang dilakukan oleh Mohammadi (2017) menyatakan bahwa keluarga mempunyai peranan penting bagi anak. Keluarga yang memiliki keserasian atau kekompakan, dapat meningkatkan prestasi akademik dan kepercayaan diri anak.
Penelitian lain mengatakan bahwa orang tua yang sering menghabiskan waktu dengan anaknya dapat mengurangi prilaku negatif pada anak (Sarwar, 2016). Oleh karena itu, orang tua harus banyak menghabiskan waktu bersama anak anaknya, dan melakukan kegiatan bersama dirumah. Cukup jelas bahwa pola asuh konvensional, seperti menghabiskan waktu bersama anak merupakan aktivitas terbaik yang perlu dicapai oleh orang tua. Cara orang tua dalam membimbing dan mendidik anak serta memberikan perlindungan dan kasih sayang dengan baik, anak dapat mengenal dirinya sendiri dengan segala keterbatasannya, merasa tidak malu atas keterbatasan yang dimiliki, memandang keterbatasan sebagai suatu realitas dan menjadikan keterbatasan itu sebagai tantangan untuk berkembang.

Pola asuh merupakan suatu sistem atau cara pendidikan dan pembinaan yang diberikan oleh seseorang pada orang lain, dalam hal ini pola asuh yang diberikan orangtua/pendidik terhadap anak adalah mengasuh dan mendidiknya dengan penuh pengertian. Hasil Study mengatakan bahwa semakin baik pola asuh orang tua, maka semakin baik pembentukan harga diri anak, begitupun sebaliknya (Zakeri \& Karimpour, 2011). Itu artinya, pola asuh merupakan peran penting untuk membentuk dan mengembangkan diri sebagai pribadi berkarakter. Setiap orangtua pasti ingin mengasuh anak anaknya dengan baik. Pola asuh orangtua mempunyai dampak secara psikologis dan sosial bagi anak serta berbentuk perilaku, jika prilaku itu baik dan bijak maka orangtua menerima dengan senang hati dan gembira, sebaliknya jika perilaku itu buruk maka yang rugi adalah orangtua dan anak akan tumbuh tidak semestinya. Kadangkala orangtua sering melupakan pola asuh terhadap anak, tidak berfikir pentingnya keamanan, kenyamanan, dan lingkungan anak. Akibat kelengahan dan ketidak waspadaan orangtua, anak banyak yang dijahili,bahkan sampai terjadinya tindakan kekerasan. Pola asuh yang diterapkan oleh orangtua juga tidak lepas dari pengaruh nilai dalam budaya tertentu terutama budaya lokal tempat menetapnya sebuah keluarga.(Nauli, Karnadi, \& Meilani, 2019) 
Menurut Surbakti (2012) Kekerasan terbagi atas dua bagian yaitu kekerasan fisik dan kekerasan verbal. Tidak banyak orang tahu kalau kekerasan yang dilakukan secara verbal atau kata kata ternyata memiliki efek yang lebih dahsyat dibandingkan dengan kekerasan fisik (Cooper Julia Marie., 2016). Ada sembilan kategori kekerasan verbal yang sering dilakukan orangtua kepada anaknya yaitu: a). Merendahkan dan mempermalukan b). Penolakan c). Menyalahkan d). Kesalahan melebih lebihkan e) ancaman f) menyumpahkan g). Penyesalah h) perbandingan yang tidak adil and i). Prediksi negatif (Loh, Calleja, \& Restubog, 2011). Didukung dalam penelitian (Armiyanti 2017) mengkaji bahwa kekerasan verbal sering kali dilakukan oleh orang terdekat khususnya orangtua. Dalam UU No. 23 Tahun 2002 tentang perlindungan anak bab IV kewajiban dan tanggung jawab orang tua yang terdapat dalam pasal 26 menegaskan "Bahwa pertanggung jawaban orang tua, keluarga masyarakat pemerintah dan negara merupakan rangkaian kegiatan yang dilandaskan secara terus menerus demi terlindungnya hak-hak anak".

Sebagian besar pemberian nama jelek berhubungan dengan kecerdasan anak, seperti, tolol, idiot, sok pintar, bodoh dll (Mackowicz 2013). Kekerasan verbal yang dilakukan orangtua merupakan salah satu hal yang menyebabkan rendahnya harga diri pada anak. Dalam menangani kekerasan verbal pada anak, bukan tindakan hukum yang diperlukan, melainkan dengan menumbuhkan kesadaran pada orang yang lebih dewasa. Penelitian lain menyatakan bahwa ketika orangtua berteriak kepada anak anaknya akan terjadi kerusakan struktur otak pada anak (Teicher 2014). Pada otak anak yang sering dibentak, saluran yang menghubungkan otak kanan dan otak kiri menjadi lebih kecil. Hal ini mempengaruhi area otak yang berhubungan dengan emosi dan perhatian. Perubahan ini pada saat anak dewasa akan menyebabkan kecemasan, depresi, dan gangguan kepribadian, resiko bunuh diri dan aktivitas otak yang mirip dengan epilepsi. Oleh sebab itu, sebagai orang tua bisa meminimalisir potensi kerusakan otak pada anak dengan cara memberikan pujian dan menegur anak dengan penuh kasih sayang. Hasil study menunjukkan bahwa kekerasan verbal berhubungan dengan fungsi neuropsikologis, dimana anak anak yang sering mengalami kekerasan verbal menderita kerentanan kognitif (Kochar, Ittyerah, \& Babu, 2015). Kekerasan verbal pada taman kanak kanak sering mengalami depresi berat dan memiliki gangguang mood yang sangat besar. Itu artinya dampak yang ditimbulkan dari kekerasan verbal lebih besar pengaruh negatifnya dalam jangka panjang (Salwen, Hymowitz, Leary, Pryor, Vivian, 2014). Itu artinya dampak yang ditimbulkan dari kekerasan verbal lebih besar pengaruh negatifnya dalam jangka panjang.

Banyak orang tua yang cenderung tegas dan keras dalam mendidik anak tidak disertai dengan niat jahat. Namun pemilihan kata orang tua kepada anak kurang tepat, salah satunya dengan memberikan kata-kata yang tidak pantas kepada anak, yang disebut dengan kekerasan verbal. Hal yang paling sering menyebabkan orang tua melakukan melakukan kekerasan verbal adalah kenalakan pada anak. Kenakalan pada anak usia dini merupakan suatu hal yang wajar, dengan cara seperti itu anak mempelajari lingkungan secara kreatif. Kebanyakan orang tua beranggapan bahwa kenakalan anak ini merupakan suatu sikap yang menganggu dan orang tua cenderung melakukan tindak kekerasan verbal pada anak seperti membentak, memaki, melabel dan sebagainya. Namun pemilihan kata kata yang tidak tepat itu dapat melukai perasaan anak, anak menjadi penakut dan hilangnya rasa percaya diri, dan hilangnya kemampuan untuk bertindak. Kemungkinan dampak tersebut akan terbawa hingga anak usia dewasa.

Kesadaran orang tua untuk menghindari kekerasan verbal pada anak mempunyai peran sangat penting sebagaimana diungkapkan oleh Febritesna Nuraini dalam penelitiannya; Orangtua sering tidak bisa memberikan pendidkan secara lansung dengan penataan lingkungan yang kondusif, oleh karenanya menjadi tugas bersama membantu merancang dan mengelola lingkungan. Penyadaran orangtua merupakan kunci utama dalam 
mengelola anak agar terbebas dari kekerasan.(Nuraini, 2016)

Berdasarkan KPAI Kasus kekerasan di Indonesia sering kali terjadi di institusi pendidikan. Hal ini dibuktikan dengan data dari Komisi Nasional Perlindungan Anak, dari tahun 2011 sampai tahun 2018 mencatat sebanyak 1664 terkait masalah tersebut. Kekerasan yang disebut KPAI sebgai bentuk kekerasan yang dilakukan disekolah (Data KPAI, 2019).

Berdasarkan studi pendahuluan yang dilakukan di SDN Rawa Badak Utara Jakarta Utara, didapatkan data dari sebagian siswa pernah melakukan perilaku kekerasan dari temannya. Adapun bentuk-bentuk kekerasan yang dominan terjadi disekolah adalah kekerasan verbal seperti mengejek dan membentak. Oleh karena itu, peneliti menganggap perlunya dilakukan penelitian yang mengkaji tentang "pengaruh pola asuh dan kekerasan verbal terhadap kepercayaan diri (self-confidence)"

\section{METODOLOGI}

Jenis penelitian yang digunakan dalam penelitian ini adalah penelitian Kuantitatif Asosiatif. Metode yang digunakan adalah metode kausal-komparatif. Penelitian ini menggunakan teknik anlisis jalur (path analysis). Pengumpulan data dalam penelitian ini dilakukan dengan menggunakan teknik non tes. Teknik non tes yaitu berupa angket. Angket untuk mengumpulkan tentang pola asuh orang tua, kepercayaan diri dan prilaku kekerasan verbal anak.

Penelitian ini dilaksanakan di SDN Rawa Badak Utara, kecamatan Koja,Kota Jakarta Utara, Provinsi DKI Jakarta. Adapun Variabel dalam penelitian ini terdiri atas variabel endogen, yaitu Kepercayaan diri (selfconfidence) dan variabel eksogen, yaitu pola asuh dan kekerasan verbal.

Populasi dalam penelitian ini yaitu seluruh peserta didik kelas II SDN se kota Jakarta Utara. Jumlah peserta didik kelas II SDN Jakarta Utara dengan jumlah 12.746 peserta didik (Sumber: Kemendikbud). Metode pengambilan Sampel dalam penelitian ini menggunakan teknik Klutser Sampling (mengambil wakil dari setiap wilayah geografis yang ada). Sedangkan jumlah minimal sampel dalam penelitian ini ditetapkan menggunakan rumus dari Solvin, diperoloeh sebanyak 99 siswa. Populasi terjangkau sebanyak 134 yang dipilih secara acak yang terdiri dari 3 Sekolah Dasar Negeri yang terdiri dari SDN Rawa Badak Utara 07 pagi ( 32 siswa), SDN Rawa Badak Utara 09 pagi (29 siswa),SDN Rawa Badak Utara 05 (45 siswa). Diperoleh sebanyak 106 siswa dengan data lengkap, dimana sudah memenuhi jumlah sampel minimal.

\section{HASIL DAN PEMBAHASAN}

\section{Pengaruh Pola asuh terhadap Kepercayaan diri (Self-Confidence)}

Dari hasil pengujian hipotesis pertama dapat disimpulkan bahwa terdapat pengaruh langsung positif pola asuh terhadap kepercayaan diri dengan nilai koefisien korelasi sebesar 0,430 dan nilai koefisien jalur sebesar 0,333. Ini memberikan makna pola asuh berpengaruh langsung positif terhadap kepercayaan diri. Dapat dilihat dari tabel berikut:

Tabel 1.1

Koefisien Jalur Pengaruh $\mathrm{X}_{1}$ terhadap $\mathrm{Y}$

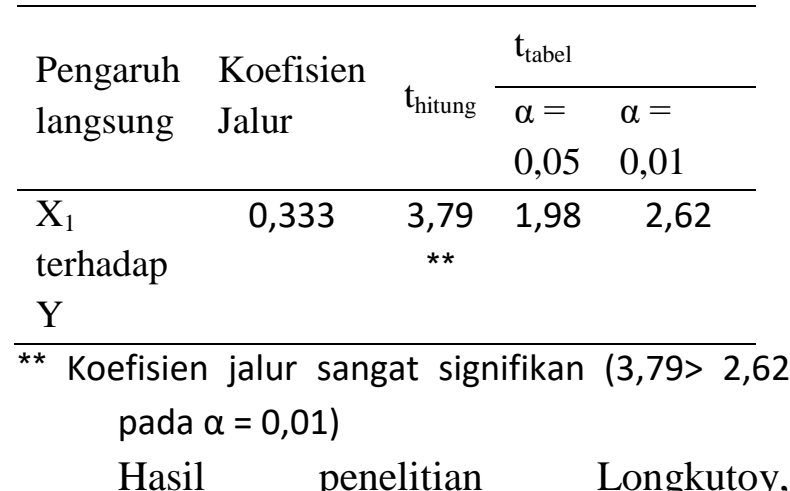

Sinolungan, \& Opod (2015)mengatakan Pola asuh orang tua mempunyai hubungan terhadap kepercayaan diri siswa, dimana semakin baik pola asuh orang tua yang diberikan kepada anak maka akan baik pula percaya diri anak. Anak akan melihat dan meniru apa yang dilakukan oleh kedua orang tuanya. Senada dengan pendapat tersebut Yusuf (2005) mengatakan Seorang anak yang dibesarkan dalam keluarga yang harmonis dan agamis,dalam arti, orang tua memberikan curahan kasih sayang, perhatian serta bimbimgan dalam kehidupan berkeluarga, 
maka perkembangan kepribadian anak tersebut cenderung positif. Oleh karena itu, sebagai orang tua harus mengetahui cara yang baik dan tepat dalam menghadapi dan mendidik anak usia dini. Sebab orang tua merupakan tauladan dan panutan anak dalam keluarga.

Pola asuh orang tua yang diberikan kepada anak dengan tepat akan membuat anak merasa dirinya berharga, dan percaya diri. Walaupun orang tua sibuk bekerja mereka wajib untuk memperhatikan perkembangan anak. orang tua harus tetap memantau, memberikan bimbingan, mengawasi dan menegur bila anak anak berada dijalur yang salah. Kondisi disekolah menunjukkan bahwa kebiasaan yang ada dilingkungan keluarga cendrung memberikan dampak terlalu menurut apa yang diminta oleh anak, sehingga anak memiliki rasa kurang percaya diri ketika melakukan kegiatan disekolah. Rasa ketergantungan anak kepada orang tua ataupun guru sangat dominan sehingga kebebasan untuk berekspresi diri anak sangat terbatas. Kondisi seperti ini menimbulkan rasa kepercayaan diri anak yang rendah.

Hasil penelitian Mohammadi (2017) menyatakan bahwa keluarga mempunyai peranan penting bagi anak. Keluarga yang memiliki keserasian atau kekompakan, dapat meningkatkan prestasi akademik dan kepercayaan diri anak. Orang tua yang selalu memberikan kasih sayang kepada anak, memarahi anak dengan cara yang wajar,dan tidak mengabaikan anak akan membuat anak merasa diterima didalam keluarga, sehingga anak merasa aman dan percaya diri.

Dari beberapa pendapat diatas telah dibuktikan bahwa kepercayaan diri memiliki pengaruh langusng positif terhadap pola asuh. Meningkatnya pola asuh mengakibatkan peningkatan kepercayaan diri.

\section{Pengaruh Kekerasan Verbal terhadap Kepercayaan Diri}

Dari hasil pengujian hipotesis kedua dapat disimpukan bahwa terdapat pengaruh langsung negatif kekerasan verbal terhadap kepercayaan diri dengan nilai koefisien korelasi sebesar -0,421 dan nilai koefisien jalur sebesar -0,319. Ini memberikan makna kekerasan verbal berpengaruh langsung negatif terhadap kepercayaan diri.

Tabel 1.2

Koefisien Jalur Pengaruh $\mathrm{X}_{2}$ terhadapY

\begin{tabular}{|c|c|c|c|c|}
\hline \multirow[b]{2}{*}{$\begin{array}{l}\text { Pengaruh } \\
\text { langsung }\end{array}$} & \multirow[b]{2}{*}{$\begin{array}{l}\text { Koefisien } \\
\text { Jalur }\end{array}$} & \multirow[b]{2}{*}{$t_{\text {hitung }}$} & \multicolumn{2}{|l|}{$t_{\text {tabel }}$} \\
\hline & & & $\begin{array}{l}\alpha= \\
0,05\end{array}$ & $\begin{array}{l}\alpha= \\
0,0 \\
1\end{array}$ \\
\hline $\mathrm{X}_{2}$ terhadap Y & $-0,319$ & $-3,63$ ** & $\begin{array}{c}- \\
1,98\end{array}$ & $\begin{array}{c}- \\
2,6\end{array}$ \\
\hline
\end{tabular}

** Koefisien jalur sangat signifikan $(-3,63<-2,62$ pada $\alpha=0,01$ )

Hasil penelitian yang dilakukan Ramadhani Asri Maulida (2017) mengatakan kekerasan verbal merupakan masalah yang cukup serius di dunia anak karena kekerasan verbal dapat menyebabkan gangguan psikologi anak seperti kurang percaya diri, tidak percaya pada orang lain, menutup diri, depresi bahkan dapat menyebabkan rasa enggan untuk pergi ke sekolah, dan beberapa kasus di luar negeri terdapat kasus pembunuhan yang dilakukan oleh seorang anak korban verbal abuse kepada teman-teman atau bahkan guru yang sudah melukaif perasaannya. Sejalan dengan penelitian penelitian Sari (2018) mengatakan bahwa dampak negatif dari kekerasan verbal bagi korban adalah ia akan merasa rendah diri, minder, kurang percaya diri, dan menarik pergaulan dari teman di sekitarnya. Namun, kekerasan verbal juga memiliki dampak positif yaitu memotivasi anak untuk menjadi lebih baik, peduli terhadap teman sesama korban bullying, dan berani untuk meningkatkan kemampuan berkomunikasinya. Bagi pelaku, kekerasan vebal menyebabkan rasa percaya dirinya meningkat dan menjadi populer diantarateman temannya sehingga hal ini berpotensi pada interaksi sosial anak yang menyebabkan peningkatan bagi kecerdasan interpersonal anak baik sebagai korban kekerasan verbal ataupun pelaku kekerasan verbal.

Perilaku kekerasan verbal sering dilakukan oleh teman sebaya. Teman sebaya juga sering memberikan pelabelan nama pada temannya dengan sebutan gendut, jelek, botak dll. Selain itu, perilaku mengkredilkan anak 
dengan mengosipkan atau menjelek jelekkan yang dilakukan teman sebaya, sudah tentu juga menimbulkan efek bagi sikorban. Di dunia pendidikan, kalau diamati, juga sering terjadi kekerasan verbal. Bisa saja hal ini dilakukan oleh guru kepada siswanya.

Dari uraian diatas dapat disimpulkan bahwa terdapat pengaruh antara kekerasan verbal dengan kepercayaan diri. Semakin tinggi kekerasan verbal yang dilakukan, maka semakin rendah kepercayaan diri pada anak.

\section{Pengaruh Pola Asuh terhadap Kekerasan Verbal}

Dari hasil perhitungan analisis jalur, pengaruh langsung pola asuh terhadap kekerasan verbal, nilai koefisien jalur sebesar 0,305 dan nilai $-t_{\text {hitung }}$ sebesar $-3,26$. Nilai $-t_{\text {tabel }}$ untuk $\alpha=0,01$ sebesar $-2,62$. Oleh karena nilai - $t_{\text {hitung }}$ lebih kecil dari pada nilai $-\mathrm{t}_{\text {tabel }}$ maka $\mathrm{H}_{0}$ ditolak dan $\mathrm{H}_{1}$ diterima, dengan demikian pola asuh berpengaruh secara langsung negatif terhadap kekerasan verbal dapat diterima.

Hasil analisis hipotesis ketiga memberikan temuan bahwa pola asuh berpengaruh secara langsung negatif terhadap kekerasan verbal. Dengan demikian dapat disimpulkan bahwa kekerasan verbal dipengaruhi secara langsung negatif oleh pola asuh. Meningkatnya pola asuh mengakibatkan penurunan kekerasan verbal.

Tabel 1.3

Koefisien Jalur Pengaruh $\mathrm{X}_{1}$ terhadap $\mathrm{X}_{2}$

\begin{tabular}{|c|c|c|c|c|}
\hline \multirow[b]{2}{*}{$\begin{array}{l}\text { Pengaruh } \\
\text { langsung }\end{array}$} & \multirow[b]{2}{*}{$\begin{array}{l}\text { Koefisie } \\
\text { n Jalur }\end{array}$} & \multirow[b]{2}{*}{$t_{\text {hitung }}$} & \multicolumn{2}{|l|}{$\mathrm{t}_{\text {tabel }}$} \\
\hline & & & $\begin{array}{l}\alpha= \\
0,05\end{array}$ & $\begin{array}{l}\alpha= \\
0,0 \\
1\end{array}$ \\
\hline$\overline{X_{1}}$ & $-0,305$ & $-3,26$ & $-1,98$ & - \\
\hline terhadap & & ** & & 2,6 \\
\hline $\mathrm{X}_{2}$ & & & & 2 \\
\hline
\end{tabular}

Keterlibatan orang tua dalam mendidik terbukti memberikan banyak dampak positif bagi anak. Ketika anak dididik dengan kasih sayang, pelukan, ciuman bisa membuat perkembangan otak anak tumbuh lebih cepat. begitupun sebaliknya apabila orang tua mendidik anak dengan penuh kemarahan, makian, bentakan maka semua energi negatif akan terserap dalam dirinya yang mungkin terbawa hingga dewasa. Sehingga saat menghadapi suatu permasalahanpun emosinya sering meledak-ledak.

Orang tua yang sewaktu kecilnya mendapat perlakuan salah merupakan situasi pencetus terjadinya kekerasan verbal pada anak (Surbakti, 2012). Semua ucapan kepada anak akan direkam dalam alam bawah sadar mereka dan akan dibawa sampai kepada masa dewasa. Anak yang mendapat perilaku kejam dari orangtuanya akan menjadi agresif dan setelah menjadi orang tua akan berlaku ejam pada anaknya. Orangtua yang agresif akan melahirkan anak-anak yang agresif, yang pada gilirannya akan menjadi orang dewasa yang agresif pula. Sikap keluarga terhadap anak yang mendapatkan kekerasan verbal memiliki peran penting dalam kehidupan anak. Dikutip dari (Janitra \& Prasanti, 2017) "Kami bukan membahas mengenai kejahilan-kejahilan yang sering terjadi dalam keluarga, tetapi mengenai insiden yang terjadi beberapa kali dalam seminggu, dimana korban diabaikan oleh saudaranya atau mengalami kekerasan verbal maupun fisik."

Anak yang terbiasa menerima bentakan, pukulan dan kemarahan saat kecil membuat anak menjadi depresi, trauma, pendiam dan sebagainya, itu merupakan hasil perbuatan orang tua yang tererkam dalam hati dan pikiran mereka.

\section{KESIMPULAN}

Terdapat pengaruh langsung pola asuh terhadap kepercayaan diri (self-confidence). Hal ini berarti bahwa pola asuh dapat meningkatkan kepercayaan diri (selfconfidence) pada anak kelas II SDN Rawa Badak Utara kota Jakarta Utara. Terdapat pengaruh langsung kekerasan verbal terhadap kepercayaan diri (self-confidence). Kekerasan verbal dapat menurunkan kepercayaan diri (self-confidence) pada anak. Anak yang sering mengalami kekerasann verbal merupakan korban. Korban kekerasan verbal cenderung memiliki tingkat kepercayaan diri yang rendah sementara pelaku kekerasan verbal memiliki 
tingkat kepercayaan diri yang lebih tinggi. Terdapat pengaruh langsung pola asuh terhadap kekerasan verbal. Pola asuh dapat meningkatkan kekerasan verbal pada anak.

\section{UCAPAN TERIMAKASIH}

Terimakasih yang sedalam-dalamnya kepada: Allah S.W.T atas limpahan karunia dan hidayahnya sehingga penulis dapat melaksanakan penelitian dan menyelesaikan karya ilmiah, Dosen pembimbing saya atas arahan dan koreksinya selama penyusunan dan penulisan karya ilmiah, kedua orang tua saya yang telah membantu dan mendukung saya dalam mengerjakan karya ilmiah ini, dan siswa siswi SDN Rawa Badak Utara atas kerjasamanya selama penulis melakukan penelitian

\section{DAFTAR PUSTAKA}

Armiyanti, Khusnul, A. (2017). Pengalaman Verbal Abuse oleh Keluarga pada Anak Usia Sekolah di Kota Semarang. 12(1).

Cooper Julia Marie. (2016). Bullying: A performance piece addressingemotional and verbal abuse between children. University of Wyoming.

Janitra, P. A., \& Prasanti, D. (2017). Komunikasi Keluarga Dalam Pencegahan Perilaku Bullying Bagi Anak. Jurnal Ilmu Sosial Mamangan, 6(1), 23. https://doi.org/10.22202/mamangan.1878

Kochar, R., Ittyerah, M., \& Babu, N. (2015). Verbal Abuse and Cognition in the Developing Mind. Journal of Agression, Maltreatment and Trauma, (August 2013).

https://doi.org/10.1080/10926771.2015.98 2236

Loh, J. M. I., Calleja, F., \& Restubog, S. L. D. (2011). Words That Hurt: A Qualitative Study of Parental Verbal Abuse in the Philippines.

https://doi.org/10.1177/088626051038303 1

Longkutoy, N., Sinolungan, J., \& Opod, H. (2015). Hubungan Pola Asuh Orang Tua dengan Kepercayaan Diri Siswa. 3(1).

Mackowicz Jolanta. (2013). Verbal Abuse in Upbringing As The Cause of Low SelfEsteem in Children. European Scientific Journal, 2.

Mohammadi, Y., Kazemi, S., Development, E., Sciences, M., Planning, C., Management,
G., ... Branch, B. (2017). the relationship of parenting style, self confidence and student's acaemic achievement. Future of Medical Education Journal, 9-13.

Nauli, V. A., Karnadi, K., \& Meilani, S. M. (2019). Peran Ibu Pedagang Pasar 24 Jam Terhadap Perkembangan Moral Anak (Penelitian Studi Kasus di Kota Bekasi). Jurnal Obsesi : Jurnal Pendidikan Anak Usia Dini, 3(1), 241. https://doi.org/10.31004/obsesi.v3i1.179

Nuraini, F. (2016). Model Penyadaran Orangtua Menggunakan Pendekatan Interaksi dalam Upaya Meminimalisir Terjadinya Kekerasan pada Anak. Jurnal Ilmiah Kependidikan, $X(1)$.

Ramadhani Asri Maulida. (2017). Jenis Kekerasan Verbal yang Diterima oleh Siswa di Lingkungan Sekolah Dasar, Respon Balik yang Diberikan, serta Program untuk Mengatasinya. 293-297.

Salwen, J. K., Hymowitz, G. F., Leary, K. D. O., Pryor, A. D., \& Vivian, D. (2014). Childhood Verbal Abuse: A Risk Factor for Depression in Pre-Bariatric Surgery Psychological Evaluations. https://doi.org/10.1007/s11695-014-12813

Sari, P. S. (2018). Hubungan Verbal Bullying dengan Kecerdasan Interpersonal Siswa SD. 3(1), 19-28.

Sarwar, S. (2016). influence of parenting style on children behaviour. Journal of Education and Education Development, 3(2), 222-249.

Surbakti. (2012). Parenting Anak-anak. Jakarta: PT. Elex Media Komputindo.

Teicher, M. (2014). Wounds That Time Won't Heal: The Neurobiology of Child Abuse. In celebrum:the dana forum on brain science.

Vanaja, Y., \& Geetha, D. (2017). a Study On Locus of Control and Self Confidence Of. 5, 598-602. https://doi.org/10.5281/zenodo.841186

Zakeri, H., \& Karimpour, M. (2011). Social and Parenting Styles and Self-esteem. Inenational Conference on Education and Education Psychology. https://doi.org/10.1016/j.sbspro.2011.11.3 02 